\title{
Kajian Pembandingan Preferensi Konsumen pada Dua Kedai Kopi di Cibinong, Kabupaten Bogor
}

\author{
Bobby Rachmat Saefudin ${ }^{1 *}$, Alvi Nurin Deaniera ${ }^{2}$, Elly Rasmikayati ${ }^{2}$ \\ ${ }^{1}$ Program Studi Agribisnis, Fakultas Pertanian, Ma'soem University \\ ${ }^{2}$ Program Studi Agribisnis, Fakultas Pertanian, Universitas Padjadjaran \\ *Email: bobbyrachmat@masoemuniversity.ac.id
}

\begin{abstract}
Abstrak
Bisnis kedai kopi merupakan salah satu usaha pemasaran agribisnis yang sedang berkembang cukup pesat di Kecamatan Cibinong, Kabupaten Bogor seiring meningkatnya konsumsi kopi serta adanya perubahan gaya hidup masyarakat. Penjualan di kedai kopi dengan lokasi usaha lebih strategis merupakan salah satu faktor yang dapat meningkatkan penjualan dibandingkan pada lokasi usaha yang kurang strategis. Namun kenyataannya, Jigana Coffee Shop yang lokasinya strategis justru pengunjungnya sedikit dan mengalami tren penurunan penjualan, sedangkan Kedai Kopi Inspirasi yang lokasinya kurang begitu strategis justru lebih ramai pengunjung dan penjualannya cenderung meningkat. Tujuan dari penelitian ini adalah untuk mengkaji dan membandingkan profil perusahaan Jigana Coffee Shop dan Kedai Kopi Inspirasi serta preferensi konsumen pada kedua kedai kopi ini. Metode penelitian yang digunakan adalah metode survey terhadap sampel 27 orang konsumen Jigana Coffee Shop dan 45 orang konsumen Kedai Kopi Inspirasi serta wawancara dengan pemilik dan karyawan kedua kedai kopi. Alat analisis yang digunakan adalah analisis kualitatif, statistika deskriptif dan uji Mann-Whitney U. Hasil penelitian menunjukkan bahwa dilihat dari struktur perusahaan, suasana bekerja dan deskripsi pekerjaan dari kedua kedai kopi ini cenderung sama. Hanya saja pemilik Kedai Kopi Inspirasi mempunyai visi dan misi selain mengenalkan dan meningkatkan konsumsi kopi masyarakat juga membuka lapangan kerja bagi orang yang putus sekolah agar bisa tetap berpenghasilan dan belajar lebih dalam mengenai kopi. Sementara itu, dari hasil uji Mann-Whitney U dapat disimpulkan bahwa banyaknya pengunjung dan meningkatnya penjualan di Kedai Kopi Inspirasi tidak terlepas dari faktor keterjangkauan harga, kelengkapan fasilitas dan suasana kedai yang tidak kalah dari Jigana Coffee Shop.
\end{abstract}

Kata kunci: Comparative study, Preferensi konsumen, Kedai kopi, Coffee Shop, Mann-Whitney U Test.

\section{Pendahuluan}

Komoditi unggul subsektor perkebunan yang memiliki potensi cukup besar dan menjanjikan untuk dikembangkan adalah kopi. Hal ini disebabkan Indonesia merupakan salah satu penghasil kopi terbesar di dunia. Saat ini Indonesia adalah Negara penghasil kopi arabika terbesar keempat di dunia (Ajijah, 2019). Disisi lain, kebutuhan serta konsumsi kopi di Indonesia juga mengalami peningkatan setiap tahunnya seiring dengan Indonesia sebagai salah satu penghasil kopi terbesar di dunia (Amir dkk., 2017). Tren peningkatan konsumsi kopi di Indonesia (Gambar 1) diantaranya disebabkan oleh perubahan tren dan pola perilaku masyarakat Indonesia yang awalnya hanya mengonsumsi makanan serta minuman di dalam rumah menjadi di luar rumah seiring dinamika perubahan zaman (Kara \& Kaynak, 1997). Selain itu, adanya peningkatan pendapatan, perubahan demografi, meningkatnya aktivitas rekreasi masyarakat global serta kemudahan dan kenyamanan dalam mendapatkan makanan dan minuman juga menjadi penyebab mengapa masyarakat global ini mengonsumsi makanan diluar rumah (Mawson and Fearne, 1996).

Hal-hal tersebut menjadi faktor pemicu meningkatnya konsumsi kopi di Indonesia sehingga membuat peluang bagi banyak pelaku usaha kedai kopi / kafe / Coffee Shop untuk mengembangkan usahanya. Kementrian
Perindustrian juga menyatakan bahwa hal-hal yang mendorong kinerja dari industri pengolahan kopi di Indonesia ini yaitu perubahan lifestyle masyarakat Indonesia serta pertumbuhan kelas menengah sehingga mengalami peningkatan yang cukup signifikan ${ }^{1}$.

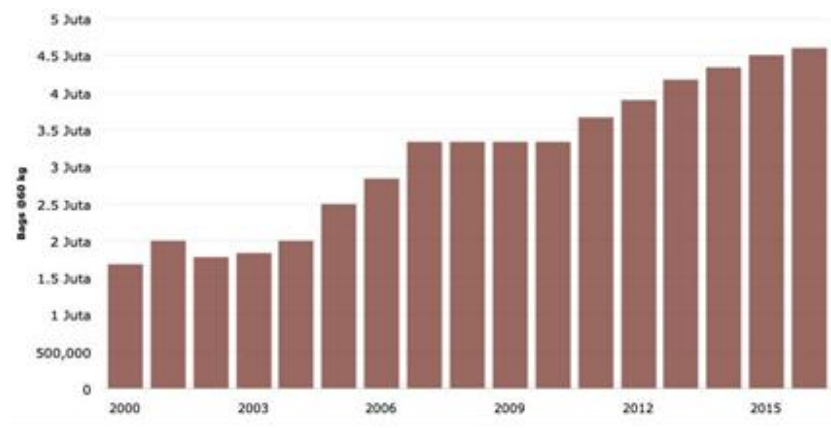

Gambar 1. Konsumsi Kopi di Indonesia hingga Tahun 2016. Sumber: ICO (2018).

Pertumbuhan usaha kedai kopi di Indonesia hingga akhir 2019 diprediksi meningkat mencapai 15\% sampai $20 \%$ jika dibandingkan di tahun 2018 yang hanya

${ }^{1} \mathrm{http} / / / \mathrm{www} . k e m e n p e r i n . g o . i d / a r t i k e l / 15421 / M e n p e r i n:-G a y a-$ Hidup-Dorong-Industri-Kopi-Tumbuh [Diakses pada 21 Maret 2020] 
mencapai $8 \%$ sampai $10 \% 2$. Pertumbuhan jumlah kedai kopi ini terjadi di berbagai wilayah, termasuk Kabupaten Bogor. Kabupaten Bogor merupakan salah satu tempat yang khas akan tempat wisata dan rekreasi. Selain itu, Kabupaten Bogor juga terkenal akan wisata kulinernya.

Saat ini, kedai kopi merupakan salah satu jenis restoran yang sedang berkembang cukup pesat di Kecamatan Cibinong. Jigana Coffee Shop dan Kedai Kopi Inspirasi merupakan usaha kedai kopi di Cibinong yang bergerak di bidang agribisnis dan memasarkan berbagai jenis kopi asli Indonesia. Jigana Coffee Shop terletak di Jl. KSR Dadi Kusmayadi, Desa Tengah, Ruko Perumahan Cibinong Griya Asri, Kecamatan Cibinong, Kabupaten Bogor, Jawa Barat. Sedangkan, Kedai Kopi Inspirasi terletak di Jl. Haji Minggu No. 29, Desa Tengah, Kecamatan Cibinong, Kabupaten Bogor, Jawa Barat.

Seiring meningkatnya konsumsi kopi serta adanya perubahan gaya hidup masyarakat Indonesia, harapannya jumlah pengunjung di kedai kopi ini mengalami peningkatan. Semakin banyak pengunjung yang datang juga akan membuat kedai kopi lebih banyak dikenal masyarakat. Merujuk pada Rasmikayati dkk. (2017), bahwa penjualan di kedai kopi dengan lokasi usaha lebih strategis merupakan salah satu faktor yang dapat meningkatkan penjualan dibandingkan pada lokasi usaha yang kurang strategis.

Namun berdasarkan hasil observasi di Jigana Coffee Shop dan Kedai Kopi Inspirasi terjadi hal yang menarik, yaitu Jigana Coffee Shop yang lokasinya strategis justru pengunjungnya sedikit dan mengalami tren penurunan penjualan, sedangkan Kedai Kopi Inspirasi yang lokasinya kurang begitu strategis justru lebih ramai pengunjung dan penjualannya cenderung meningkat. Berdasarkan hasil obeservasi didapatkan rata-rata penjualan kopi dari bulan Oktober 2019 hingga Januari 2020 di Jigana Coffee Shop hanya sebesar 140 piece setiap bulannya, sedangkan ratarata penjualan kopi di Kedai Kopi Inspirasi untuk periode yang sama adalah 2294 piece per bulan.

Keadaan yang kontradiktif seperti itu disebabkan oleh perbedaan preferensi konsumen terhadap kedua kedai kopi tersebut. Preferensi konsumen dapat diketahui dengan mengukur tingkat kegunaan serta nilai relatif penting dari setiap atribut terkait yang ingin dinilai (Febrianti dkk, 2019). Berdasarkan hal tersebut, peneliti tertarik untuk mengkaji dan membandingkan profil Jigana Coffee Shop dan Kedai Kopi Inspirasi serta preferensi konsumen pada kedua kedai kopi ini.

\section{Kerangka Teori}

\section{1) Bisnis Kedai Kopi}

Bisnis merupakan suatu bentuk kerja sama yang melibatkan produksi, pertukaran, serta distribusi barang dan jasa untuk mencapai suatu tujuan nilai kolektif (Donaldson \& Walsh, 2015). Sedangkan, kedai kopi merupakan tempat yang menyediakan produk kopi beserta produk turunannya sebagai minuman utama dan berbagai

${ }^{2}$ https://ekonomi.bisnis.com/read/20190822/12/1139918/industrikedai-kopi-ditaksir-tumbuh-20-tahun-ini [Diakses pada 21 Maret 2020] jenis minuman sampingan lainnya seperti teh, cokelat serta makanan ringan yang biasanya ditawarkan sebagai menu hidangan pendamping minum kopi. Dapat disimpulkan bahwa bisnis kedai kopi merupakan suatu bentuk kerja sama yang menyediakan produk atau layanan, khususnya kopi sebagai minuman utama dan berbagai minuman serta makanan sampingan lainnya dengan bentuk kedai, warung, atau kafe untuk mencapai keuntungan dalam memenuhi kebutuhan masyarakat.

Dalam bisnis, terdapat ketidakstabilan lingkungan yang berkelanjutan dimana para pemimpin organisasi beroperasi karena berbagai faktor seperti (a) sosial ekonomi, (b) budaya, dan (c) masalah politik serta (d) perubahan kebutuhan dan preferensi pelanggan, (e) kompetisi yang muncul, (f) kurangnya kontrol, dan keputusan yang kompleks (Psychogios \& Garev, 2012). Untuk memulai sebuah usaha di bidang pengolahan kopi, passion merupakan hal utama yang harus dimiliki oleh pelaku usaha. Selain passion, model bisnis yang tepat juga diperlukan dengan tujuan untuk menghindari kesalahan dasar para pelaku usaha yang baru saja memulai bisnis usahanya.

Salah satu bisnis yang memiliki prospek menjanjikan adalah bisnis kedai kopi. Hal tersebut dikarenakan bisnis kedai kopi ini selain menjadi tempat untuk menikmati kopi juga biasanya digunakan sebagai tempat untuk melakukan aktifitas seperti mengerjakan tugas kuliah, rapat dan berdiskusi (Latifa dan Rochdiani, 2019). Menurut Rasmikayati dkk. (2017), tren pertumbuhan kedai kopi di Indonesia menunjukkan peningkatan dari tahun 2011 sampai 2016 sebesar 189 unit untuk kedai kopi franchise dan 40 unit untuk kedai kopi independen atau lokal.

\section{2) Preferensi Konsumen}

Sumarwan dkk. (2012) mendefinisikan preferensi sebagai suatu pilihan, kesukaan atau suatu hal yang lebih disukai oleh konsumen. Menurut Rochaeni (2013), preferensi konsumen diartikan sebagai sebuah keputusan evaluasi konsumen yang mempertimbangkan dua objek didalamnya atau lebih karena akan selalu melibatkan perbandingan antar objek. Menurut Kotler dan Amstrong (2003), preferensi konsumen didefinisikan sebagai kecenderungan seseorang terhadap kesukaan mereka pada suatu produk (barang atau jasa) dari berbagai pilihan produk yang ada.

Penelitian mengenai preferensi konsumen kopi antara lain: (1) Asioli et al., (2016) menyatakan bahwa konsumen lebih memilih produk es kopi rendah kalori dan harga yang lebih murah. (2) Loo et al., (2015) menjelaskan dalam penelitiannya mengenai beberapa hasil penelitian terdahulu bahwa kopi fair trade umumnya lebih disukai daripada kopi organik oleh konsumen Belgia, Jerman, dan Amerika Serikat.

\section{Metodologi (Time New Roman, 10 Bold)}

\section{1) Objek dan Lokasi Penelitian}

Objek penelitian ini adalah profil Jigana Coffee Shop dan Kedai Kopi Inspirasi serta preferensi konsumen di kedua kedai kopi tersebut. Pemilihan dua kedai kopi tersebut dikarenakan keduanya mempunyai karakteristik yang berbeda. Jigana Coffee Shop lokasi kedainya strategis 
tapi pengunjungnya sedikit dan mengalami tren penurunan penjualan, sedangkan Kedai Kopi Inspirasi lokasinya kurang begitu strategis namun justru pengunjungnya lebih ramai dan penjualannya cenderung meningkat.

\section{2) Desain dan Metode Penelitian}

Penelitian ini menggunakan desain penelitian mix method yaitu menggabungkan desain kualitatif dan kuantitatif. Desain kualitatif dilakukan dengan mewancarai key informan yaitu pemilik dan karyawan Jigana Coffee Shop dan Kedai Kopi Inspirasi. Sedangkan desain kuantitatif dilakukan dengan metode survey pada konsumen Jigana Coffee Shop dan Kedai Kopi Inspirasi.

Teknik sampling yang digunakan adalah systematic sampling method atau teknik sampling sistematis yang merupakan teknik penentuan sampel yang dilakukan berdasarkan nomor urut anggota populasi (Sugiyono 2018). Penentuan jumlah sampel yang diteliti dilakukan berdasarkan perhitungan rumus Cochran sedemikian rupa sehingga didapatkan ukuran sampel sebesar 27 responden untuk konsumen Jigana Coffee Shop dan 45 responden untuk konsumen Kedai Kopi Inspirasi.

\section{3) Variabel Penelitian}

Variabel penelitian ini terdiri profil perusahaan dan preferensi konsumen Jigana Coffee Shop dan Kedai Kopi Inspirasi. Variabel profil perusahaan terdiri dari atribut sejarah berdirinya perusahaan, struktur perusahaan, visi misi, suasana bekerja dan job description. Sedangkan variabel preferensi konsumen terdiri atas atribut kualitas produk, kualitas pelayanan, harga yang ditawarkan, fasilitas kedai, kebersihan dan kerapihan, suasana kedai, dan kestrategisan lokasi kedai.

\section{4) Teknik Analisis Data}

Teknik analisis data yang digunakan untuk mengkaji dan membandingkan profil perusahaan Jigana Coffee Shop dan Kedai Kopi Inspirasi adalah menggunakan analisis kualitatif. Sedangkan untuk mengkaji dan membandingkan preferensi konsumen Jigana Coffee Shop dan Kedai Kopi Inspirasi digunakan statistika deskriptif berupa tabel distribusi frekuensi dan analisis nonparametric berupa uji beda peringkat Mann-Whitney $U$.

\section{Hasil dan Pembahasan}

\subsection{Profil Jigana Coffee Shop dan Kedai Kopi Inspirasi 1) Jigana Coffee Shop}

Jigana Coffee Shop terletak di Ruko Perumahan Cibinong Griya Asri, Bogor, Jawa Barat yang didirikan oleh sepasang suami istri yaitu Kriesna Kurnia Pratama dan Sri Rahayu yang juga biasa dipanggil Cici. Jigana Coffee Shop ini didirikan pada tahun 2019, tepatnya dibuka pada bulan April. Berdirinya kedai kopi ini dilatarbelakangi dengan ketertarikan pemilik terhadap komoditas kopi melalui film filosofi kopi yang pertama pada tahun 2015 serta keinginan untuk mempopulerkan kopi nusantara yang tidak kalah dengan kopi Ethiopia ataupun Brazil kepada masyarakat sekitar yang belum aware dengan original coffee, khususnya di Cibinong.

Pada tahun 2015, pemilik mulai belajar mendalami komoditas kopi di manual brew V60. Setelah itu, pada tahun 2017 pemilik sering berkunjung ke berbagai kedai kopi untuk menikmati serta mengamati peluang bisnis kedai kopi sehingga pada akhirnya pemilik tertarik untuk membuka bisnis kedai kopi. Di pertengahan tahun 2017, pemilik resign dari kerjaannya untuk belajar berbisnis serta mendalami lebih lagi mengenai komoditas kopi. Pada tahun 2019, pemilik diberi modal oleh orang tuanya untuk membuka suatu usaha yang akhirnya didirikanlah Jigana Coffee Shop.

Jigana Coffee Shop mempunyai visi dan misi, yaitu ingin mengenalkan minuman kopi yang sekelas dengan Coffee Shop di mall dengan harga yang terjangkau untuk meningkatkan kualitas budaya ngopi yang sehari ditengah masyarakat. Visi dan misi ini juga terlihat dari bahan baku biji kopi yang digunakan dengan kualitas yang baik.

Struktur perusahaan Jigana Coffee Shop dapat dikatakan sangat sederhana karena hanya pemilik yang merangkap sebagai manajer dan marketing sekaligus karyawan. Pimpinan tertinggi dipegang oleh pemilik yang juga sekaligus menjabat sebagai supervisor yang mempunyai wewenang dalam hal pengambilan keputusan tertinggi dalam menentukan kebijakan serta rencana perusahaan.

Suasana antar pekerja di Jigana Coffee Shop ini juga diciptakan senyaman mungkin untuk menghilangkan rasa kaku dan kesenjangan antar pemilik dengan karyawan. Semua elemen pekerja memegang peranan yang penting dalam kemajuan perusahaan sehingga antar sesama karyawan dapat membantu dalam menjalankan tugas. Hal yang paling utama ditekankan oleh pemiliki kepada karyawan ialah keramahan terhadap konsumen dengan cara interaksi aktif antara karyawan dengan konsumen ketika sedang melayani pembelian.

Jigana Coffee Shop ini memiliki dua orang pekerja. Pemilik yang merangkap sebagai manajer dan marketing dibantu oleh istri pemilik yang bertanggung jawab untuk memantau semua kebutuhan bahan baku serta bagian dapurnya. Selain itu, pemilik juga berperan sebagai supervisor untuk memantau para pekerja dan juga ikut terjun langsung dalam melayani konsumen.

Untuk job description di Jigana Coffee Shop ini dibagi dua bagian, yaitu bagian barista yang dipegang penuh oleh pemilik dan bagian dapur yang dipegang penuh oleh istri pemilik. Namun, untuk selalu menjaga kebersihan itu merupakan tugas dan kewajiban seluruh pekerja sehingga tidak ada pembagian job description khusus karena hal tersebut merupakan tanggung jawab semua.

\section{2) Kedai Kopi Inspirasi}

Kedai Kopi Inspirasi terletak di Jalan Haji Minggu No. 29, Tengah, Cibinong, Bogor Jawa Barat. Kedai kopi ini didirikan pada tanggal 6 Februari 2017 oleh seseorang bernama Agus Widarso. Berdirinya kedai kopi ini dilatarbelakangi dari keinginan dari salah satu orang yang hanya sekedar iseng ingin memiliki tempat kedai kopi. Rencana awal lokasi tempat kedai kopi juga bukan di tempat yang sekarang, melainkan di dekat lapangan Calcio, Cibinong. Bahkan tempatnya pun sudah dibangun setengah jadi oleh pemilik pada saat itu. Namun, karena ada beberapa hal kendala didalam perjalanannya, maka dari itu lokasinya berpindah menjadi lokasi ditempat sekarang. 
Pada awalnya, pemilik serta pengelola tidak percaya diri untuk membangun usaha tempat kedai kopinya di lokasi usaha yang sekarang. Alasan utamanya yaitu dikarenakan bahwa di lokasi usaha yang sekarang itu berada di dalam gang. Selain itu, adanya kebun jati juga membuat pemilik dan pengelola merasa pesimis karena pada saat itu belum ada kedai kopi di daerah Cibinong yang memakai konsep tersebut serta apabila sedang musim gugur, kedai kopi ini akan lebih terlihat berantakan karena daun yang berguguran jatuh.

Kedai Kopi Inspirasi ini tidak memiliki visi dan misi tertulis. Namun, visi dan misi Kedai Kopi Inspirasi pada awalnya yaitu untuk membuka lapangan kerja bagi orang yang putus sekolah disekitar lokasi usaha. Hal tersebut bertujuan agar mereka bisa tetap berpenghasilan. Tidak hanya berpenghasilan saja, tetapi juga mereka dapat belajar lebih dalam mengenai kopi sehingga mereka dapat meningkatkan skill mereka di bidang lain selain akademik sekolah. Selain itu, tujuan didirikannya kedai kopi ini juga untuk mengedukasi kopi kepada masyarakat sekitar yang belum mengetahui kopi lebih dalam.

Struktur perusahaan di Kedai Kopi Inspirasi Cibinong dapat dikatakan sederhana, dimana masing-masing bekerja pada posisi yang telah ditetapkan. Pimpinan tertinggi dipegang oleh pemilik kedai kopi. Struktur ini berfungsi untuk memberikan informasi tugas pada masing-masing pekerja, serta menggambarkan arah kordinasi yang ada diantaranya. Pemilik kedai kopi di Kedai Kopi Inspirasi diduduki oleh Bapak Agus Widarso, dengan tugas mengatur bisnis agar berjalan dengan lancar dan sesuai dengan tujuan yang telah ditetapkan sebelumnya. Di bawah pemilik kedai, terdapat pengelola yang diduduki oleh Kak Arie Sofyan sebagai penanggung jawab dari bisnis kedai kopi ini. Tugasnya yaitu mengelola dan mengawasi segala proses bisnis yang terjadi dilapangan. Di bawah pengelola, terdapat dua bagian karyawan, yaitu bagian barista dan dapur.

\subsection{Perbandingan Preferensi Konsumen Jigana Coffee Shop dan Kedai Kopi Inspirasi}

Atribut-atribut preferensi konsumen Jigana Coffee Shop dan Kedai Kopi Inspirasi yang akan dibandingkan adalah mengenai kualitas produk, kualitas pelayanan, harga yang ditawarkan, fasilitas yang ditawarkan, kebersihan dan kerapihan kedai kopi, suasana tempat yang ditawarkan, dan kestrategisan lokasi kedai.

\section{1) Kualitas Produk}

Kualitas produk merupakan karakter dari sebuah produk itu sendiri yang berpotensi memiliki kemampuan untuk dapat memenuhi kebutuhan konsumen (Kotler and Amstrong, 2014). Apabila sebuah perusahaan ingin mempertahankan keunggulannya dari kompetitif yang lainny dalam pasar, maka perusahaan tersebut juga harus mengerti aspek apa saja yang digunakan konsumen untuk dapat membedakan produk perusahaan dengan produk pesaing sejenis lainnya (Mullins et al., 2005). Hasil analisis perbandingan respons konsumen mengenai kualitas produk Jigana Coffee Shop dan Kedai Kopi Inspirasi tersaji pada Tabel 1.
Hasil Analisis Perbandingan Respons Konsumen Mengenai Kualitas Produk Jigana Coffee Shop dan Kedai Kopi Inspirasi

\begin{tabular}{|c|c|c|c|c|c|c|}
\hline \multirow[b]{2}{*}{ No. } & \multirow{2}{*}{$\begin{array}{c}\text { Respons } \\
\text { Kualitas } \\
\text { Produk }\end{array}$} & \multicolumn{2}{|c|}{ Jigana Coffee Shop } & \multicolumn{2}{|c|}{ Kedai Kopi Inspirasi } & \multirow{2}{*}{$\begin{array}{l}\text { Nilai } \\
\text { Sig.* }\end{array}$} \\
\hline & & $\begin{array}{l}\text { Frekuensi } \\
\text { (Orang) }\end{array}$ & $\begin{array}{c}\text { Persentase } \\
(\%)\end{array}$ & $\begin{array}{c}\text { Frekuensi } \\
\text { (Orang) }\end{array}$ & $\begin{array}{c}\text { Persentase } \\
(\%)\end{array}$ & \\
\hline 1 & Sangat baik & 16 & 59 & 11 & 24 & \multirow{5}{*}{0,003} \\
\hline 2 & Baik & 11 & 41 & 32 & 69 & \\
\hline 3 & Tidak baik & - & - & 2 & 7 & \\
\hline & Total & 27 & 100 & 45 & 100 & \\
\hline \multicolumn{3}{|c|}{ Peringkat rata-rata* } & 44.74 & \multicolumn{2}{|c|}{31.56} & \\
\hline
\end{tabular}

Ket: *Berdasarkan hasil Mann-Whitney U Test

Berdasarkan hasil Mann-Whitney U Test pada Tabel 1, dapat disimpulkan bahwa terdapat perbedaan yang signifikan (nilai sig. $=0,003<$ taraf nyata $5 \%$ ) dalam hal kualitas produk antara Jigana Coffee Shop dan Kedai Kopi Inspirasi. Dengan nilai peringkat rata-rata kualitas produk Jigana Coffee Shop yang lebih besar dari pada Kedai Kopi Inspirasi mengindikasikan bahwa konsumen menilai bahwa kualitas produk Jigana Coffee Shop lebih baik dari pada Kedai Kopi Inspirasi.

Mayoritas responden Jigana Coffee Shop berpendapat bahwa kualitas produk kopi yang ditawarkan sangatlah baik dengan persentase terbesar, yaitu 59 persen. Sisanya merasa bahwa kualitas produk kopi yang ditawarkan sudah baik dengan persentase 41 persen. Harapan kebanyakan responden mengenai kualitas produk kopi di Jigana Coffee Shop yaitu agar pemilik terus dapat meracik kopi yang sesuai dengan selera konsumen, semakin banyak jenisjenis kopi yang ditawarkan baik nusantara maupun lokal (Bogor), serta memperbaiki teknik brewing-nya.

Berbeda halnya dengan Kedai Kopi Inspirasi yang mayoritas respondennya memilih baik pada kualitas produk yang ditawarkan dengan persentase 69 persen. Hal ini dikarenakan sebagian responden dari Kedai Kopi Inspirasi merasa bahwa kualitas produk kopi yang ditawarkan kurang baik sehingga banyak konsumen yang berharap agar Kedai Kopi Inspirasi memperbanyak jenisjenis kopi yang asli Jawa dan memperbaiki rasa dari kopi espresso based-nya. Hasil penelitian ini juga memiliki kesamaan dengan penelitian Anisailah (2017) yang menyatakan bahwa kualitas produk suatu kedai kopi sudah cukup baik namun dari sisi proses pembuatannya masih belum menghasilkan cita rasa yang konsisten dan sesuai dengan selera konsumen. Lebih jauh lagi, kualitas produk merupakan salah satu faktor yang berpengaruh nyata meningkatkan kepuasan pelanggan (Rasmikayati dkk., 2020).

\section{2) Kualitas Pelayanan}

Selanjutnya, variabel yang diteliti adalah kualitas pelayanan, yaitu tingkat keunggulan yang diharapkan sehingga dapat memenuhi harapan konsumen (Lovelock, 2002). Menurut Faradisa dkk. (2016), sebuah perusahaan harus dapat menciptakan atau mewujudkan kualitas pelayanan menurut syarat-syarat yang diajukan atau dituntut oleh pelanggan. Hasil analisis perbandingan respons konsumen mengenai kualitas pelayanan Jigana Coffee Shop dan Kedai Kopi Inspirasi tersaji pada Tabel 2.

Tabel 1 
Tabel 2

Hasil Analisis Perbandingan Respons Konsumen Mengenai Kualitas Pelayanan Jigana Coffee Shop dan Kedai Kopi Inspirasi

\begin{tabular}{|c|c|c|c|c|c|c|}
\hline \multirow[b]{2}{*}{ No. } & \multirow{2}{*}{$\begin{array}{l}\text { Respons } \\
\text { Kualitas } \\
\text { Pelayanan }\end{array}$} & \multicolumn{2}{|c|}{ Jigana Coffee Shop } & \multicolumn{2}{|c|}{ Kedai Kopi Inspirasi } & \multirow{2}{*}{$\begin{array}{l}\text { Nilai } \\
\text { Sig.* }\end{array}$} \\
\hline & & $\begin{array}{l}\text { Frekuensi } \\
\text { (Orang) }\end{array}$ & $\begin{array}{c}\text { Persentase } \\
(\%)\end{array}$ & $\begin{array}{c}\text { Frekuensi } \\
\text { (Orang) }\end{array}$ & $\begin{array}{c}\text { Persentase } \\
(\%)\end{array}$ & \\
\hline 1 & Memuaskan & 19 & 70 & 14 & 31 & \multirow{5}{*}{0,000} \\
\hline 2 & Biasa saja & 7 & 26 & 28 & 62 & \\
\hline 3 & $\begin{array}{l}\text { Tidak } \\
\text { memuaskan }\end{array}$ & 1 & 4 & 3 & 7 & \\
\hline & Total & 27 & 100 & 45 & 100 & \\
\hline \multicolumn{3}{|c|}{ Peringkat rata-rata* } & 6.56 & \multicolumn{2}{|c|}{30.47} & \\
\hline
\end{tabular}

Ket: *Berdasarkan hasil Mann-Whitney U Test

Berdasarkan hasil Mann-Whitney U Test pada Tabel 2, dapat disimpulkan bahwa terdapat perbedaan yang signifikan (nilai sig. $=0,000<$ taraf nyata $5 \%$ ) dalam hal kualitas pelayanan antara Jigana Coffee Shop dan Kedai Kopi Inspirasi. Dengan nilai peringkat rata-rata kualitas pelayanan Jigana Coffee Shop yang lebih besar dari pada Kedai Kopi Inspirasi mengindikasikan bahwa konsumen menilai bahwa kualitas pelayanan Jigana Coffee Shop lebih baik dari pada Kedai Kopi Inspirasi.

Konsumen Jigana Coffee Shop kebanyakan merasa puas terhadap kualitas pelayanan yang ditawarkan oleh kedai kopi tersebut dengan persentase terbesar, yaitu 70 persen. Sebagian responden merasa bahwa kualitas pelayanan yang ditawarkan oleh Jigana Coffee Shop ini masih biasa saja, bahkan tidak memuaskan. Harapan dari responden yang merasa tidak puas dengan kualitas pelayanan kedai kopi tersebut yaitu dengan dilakukannya penambahan pekerja karena pada saat ramai, pelayanannya cenderung lama.

Sedangkan pada Kedai Kopi Inspirasi, mayoritas responden kedai kopi tersebut merasa biasa saja terhadap kualitas pelayanan yang ditawarkan. Menurut sebagian responden, hal tersebut dikarenakan service untuk konsumennya masih kurang, sistem pemesanan dan pembayaran yang kurang efisien, pelayanan yang sedikit lama bahkan kadang lupa untuk mengantarkan pesanannya terlebih jika keadaan kedai kopi sedang sangat ramai.

\section{3) Harga yang Ditawarkan}

Variabel selanjutnya diteliti oleh penulis adalah harga. Harga adalah sejumlah uang yang dibebankan atas suatu produk maupun jasa, atau bahkan jumlah dari nilai yang ditukar konsumen atas manfaat-manfaat karena memiliki atau menggunakan produk atau jasa tersebut (Kotler \& Amstrong, 2012). Menurut Satit et al. (2012), harga merupakan salah satu elemen bauran pemasaran yang paling mempengaruhi keputusan pembelian pelanggan. Penawaran harga yang menarik juga merupakan salah satu cara untuk mempertahankan pelanggan yang sudah ada. Hasil analisis perbandingan respons konsumen mengenai harga yang ditawarkan oleh Jigana Coffee Shop dan Kedai Kopi Inspirasi tersaji pada Tabel 3.

Hasil Mann-Whitney $U$ Test pada Tabel 3 menunjukkan bahwa tidak terdapat perbedaan yang signifikan (nilai sig. $=0,438>$ taraf nyata $5 \%$ ) dalam hal harga yang ditawarkan antara Jigana Coffee Shop dan Kedai Kopi Inspirasi. Hal ini mengindikasikan bahwa konsumen menilai bahwa harga yang ditawarkan Jigana Coffee Shop sama dengan Kedai Kopi Inspirasi.

Tabel 3

Hasil Analisis Perbandingan Respons Konsumen Mengenai Harga yang Ditawarkan Jigana Coffee Shop dan Kedai Kopi Inspirasi

\begin{tabular}{|c|c|c|c|c|c|c|}
\hline \multirow[b]{2}{*}{ No. } & \multirow{2}{*}{$\begin{array}{c}\text { Respons } \\
\text { Harga }\end{array}$} & \multicolumn{2}{|c|}{ Jigana Coffee Shop } & \multicolumn{2}{|c|}{ Kedai Kopi Inspirasi } & \multirow{2}{*}{$\begin{array}{l}\text { Nilai } \\
\text { Sig.* }\end{array}$} \\
\hline & & $\begin{array}{c}\text { Frekuensi } \\
\text { (Orang) }\end{array}$ & $\begin{array}{c}\text { Persentase } \\
(\%)\end{array}$ & $\begin{array}{c}\text { Frekuensi } \\
\text { (Orang) }\end{array}$ & $\begin{array}{l}\text { Persentase } \\
(\%)\end{array}$ & \\
\hline 1 & Murah & 9 & 33 & 16 & 36 & \multirow{4}{*}{0,438} \\
\hline 2 & Sedang & 15 & 56 & 29 & 64 & \\
\hline 3 & Mahal & 3 & 11 & - & - & \\
\hline & Total & 27 & 100 & 45 & 100 & \\
\hline & gkat rata-r & & 8.61 & & & \\
\hline
\end{tabular}

Ket: *Berdasarkan hasil Mann-Whitney U Test

Mayoritas responden Jigana Coffee Shop dan Kedai Kopi Inspirasi berpendapat bahwa harga yang ditawarkan oleh kedua kedai kopi tersebut tergolong pada kategori sedang dan murah, dimana dapat disimpulkan bahwa harga produk yang ditawarkan tidak murah, dan tidak juga mahal (relatif terjangkau). Sebenarnya, persentase respons konsumen yang menganggap harga yang ditawarkan oleh Kedai Kopi Inspirasi terjangkau (murah dan sedang) lebih banyak dari pada Jigana Coffee Shop namun perbedaan ini tidak signifikan secara statistik. Dengan demikian dapat disimpulkan bahwa harga yang ditawarkan Jigana Coffee Shop dan Kedai Kopi Inspirasi sama-sama terjangkau oleh konsumen.

\section{4) Fasilitas yang Ditawarkan}

Selanjutnya, variabel yang diteliti adalah fasilitas yang ditawarkan. Menurut Tjiptono (2006), fasilitas merupakan bagian dari physical evidence, yang secara garis besar meliputi fasilitas fisik organisasi dan bentuk komunikasi fisik lainnya. Hasil analisis perbandingan respons konsumen mengenai fasilitas yang ditawarkan oleh Jigana Coffee Shop dan Kedai Kopi Inspirasi tersaji pada Tabel 4.

Tabel 4

Hasil Analisis Perbandingan Respons Konsumen Mengenai Fasilitas yang Ditawarkan Jigana Coffee Shop dan Kedai Kopi Inspirasi

\begin{tabular}{|c|c|c|c|c|c|c|}
\hline \multirow[b]{2}{*}{ No } & \multirow{2}{*}{$\begin{array}{l}\text { Respons } \\
\text { Fasilitas }\end{array}$} & \multicolumn{2}{|c|}{ Jigana Coffee Shop } & \multicolumn{2}{|c|}{ Kedai Kopi Inspirasi } & \multirow{2}{*}{$\begin{array}{l}\text { Nilai } \\
\text { Sig.* }\end{array}$} \\
\hline & & $\begin{array}{l}\text { Frekuensi } \\
\text { (Orang) }\end{array}$ & $\begin{array}{c}\text { Persentase } \\
(\%)\end{array}$ & $\begin{array}{c}\text { Frekuensi } \\
\text { (Orang) }\end{array}$ & $\begin{array}{c}\text { Persentase } \\
(\%)\end{array}$ & \\
\hline 1 & Lengkap & 4 & 15 & 6 & 13 & \multirow{5}{*}{0,565} \\
\hline & $\begin{array}{l}\text { Kurang } \\
\text { lengkap }\end{array}$ & 23 & 85 & 37 & 82 & \\
\hline 3 & $\begin{array}{l}\text { Tidak } \\
\text { lengkap }\end{array}$ & - & - & 2 & 5 & \\
\hline & Total & 27 & 100 & 45 & 100 & \\
\hline \multicolumn{3}{|c|}{ Peringkat rata-rata* } & 37.69 & \multicolumn{2}{|c|}{35.79} & \\
\hline
\end{tabular}

Ket: *Berdasarkan hasil Mann-Whitney U Test

Hasil Mann-Whitney $U$ Test pada Tabel 4 menunjukkan bahwa tidak terdapat perbedaan yang signifikan (nilai sig. $=0,565>$ taraf nyata $5 \%$ ) dalam hal fasilitas yang ditawarkan antara Jigana Coffee Shop dan Kedai Kopi Inspirasi. Hal ini mengindikasikan bahwa 
konsumen menilai bahwa fasilitas yang ditawarkan Jigana Coffee Shop sama dengan Kedai Kopi Inspirasi.

Mayoritas responden Jigana Coffee Shop dan Kedai Kopi Inspirasi keduanya berpendapat bahwa fasilitas yang ditawarkan oleh kedua kedai kopi tersebut masih kurang lengkap. Alasan kebanyakan responsen terkait kurang lengkapnya fasilitas di kedua kedai kopi ini yaitu mereka mengeluhkan bahwa kedua kedai ini masih belum memiliki akses wifi. Fasilitas yang sesuai dengan harapan konsumen ini akan dapat lebih menarik perhatiannya untuk datang dan berkunjung, sehingga akan berdampak pada perusahaan yang dapat memenangkan persaingan bisnisnya (Yuriansyah, 2013). Selain itu, merujuk pada Amridha dkk. (2020), perbaikan fasilitas di perusahaan akan meningkatkan kepuasan pelanggan.

Jika dibandingkan antara Jigana Coffee Shop dan Kedai Kopi Inspirasi, responden Kedai Kopi Inspirasi yang menganggap fasilitas yang ditawarkan masih kurang lengkap persentasenya lebih kecil dibandingkan Jigana Coffee Shop, dan ada 5\% responden Kedai Kopi Inspirasi yang merasa bahwa fasilitas yang ditawarkan oleh Kedai Kopi Inspirasi tidak lengkap. Hal ini dikarenakan masih terdapat responden yang merasa bahwa fasilitas yang ditawarkan Kedai Kopi Inspirasi ini tidak lengkap. Alasannya karena kedai kopi tersebut masih belum memiliki fasilitas penerangan yang cukup, lahan parkir yang belum memadai, serta kurangnya pemutar lagu. Sehingga harapan mayoritas responden yaitu Kedai Kopi Inspirasi masih perlu merapihkan serta menambahkan fasilitas yang kurang agar dapat menarik lebih perhatian konsumen untuk datang. Namun demikian secara keseluruhan dapat disimpulkan bahwa konsumen menganggap fasilitas yang ditawarkan Jigana Coffee Shop dan Kedai Kopi Inspirasi sama-sama sudah cukup bagus namun masih kurang lengkap.

\section{5) Kebersihan dan Kerapihan Kedai}

Kebersihan dan kerapihan suatu tempat juga termasuk dalam salah satu pertimbangan konsumen untuk datang. Menurut Gerry et al., (2019), kepuasan konsumen sangat dipengaruhi oleh kebersihan, kerapihan serta kenyamanan suatu tempat sehingga hal tersebut perlu diperhatikan oleh seorang pelaku usaha. Hasil analisis perbandingan respons konsumen mengenai kebersihan dan kerapihan Jigana Coffee Shop dan Kedai Kopi Inspirasi tersaji pada Tabel 5.

Hasil Mann-Whitney $U$ Test pada Tabel 5 menunjukkan bahwa terdapat perbedaan yang signifikan (nilai sig. $=0,000<$ taraf nyata 5\%) dalam hal kebersihan dan kerapihan kedai antara Jigana Coffee Shop dan Kedai Kopi Inspirasi. Dengan nilai peringkat rata-rata kebersihan dan kerapihan kedai Jigana Coffee Shop yang lebih besar dari pada Kedai Kopi Inspirasi mengindikasikan bahwa konsumen menilai bahwa Jigana Coffee Shop lebih baik kebersihan dan kerapihannya dari pada Kedai Kopi Inspirasi.

Sebagian besar responden Jigana Coffee Shop berpendapat bahwa kebersihan dan kerapihan kedai kopi tersebut sudah rapih, bahkan selalu terlihat bersih dan rapih sehingga membuat mereka nyaman berada di dalam kedai pada waktu yang lama. Berbeda halnya dengan Kedai Kopi Inspirasi, sebagian responden merasa bahwa kedai kopi tersebut masih kurang bersih. Menurut sebagian responden Kedai Kopi Inspirasi, mungkin kedai kopi ini perlu melakukan pembersihan setiap hari agar selalu terlihat bersih dan rapih. Terdapat sebagian kecil responden Kedai Kopi Inspirasi yang berpendapat bahwa kebersihan dan kerapihan kedai kopi tersebut sudah bersih. Menurut mereka, Kedai Kopi Inspirasi ini sudah cukup nyaman karena kursi dan meja masih rapih dan pihak kedai selalu membersihkan seluruh bagian kedai per satu bulan sekali.

Tabel 5

Hasil Analisis Perbandingan Respons Konsumen Mengenai Kebersihan dan Kerapihan Jigana Coffee Shop dan Kedai Kopi Inspirasi

\begin{tabular}{|c|c|c|c|c|c|c|}
\hline \multirow{2}{*}{ No. } & \multirow{2}{*}{$\begin{array}{c}\text { Respons } \\
\text { Kebersihan, } \\
\text { Kerapihan }\end{array}$} & \multicolumn{2}{|c|}{ Jigana Coffee Shop } & \multicolumn{2}{|c|}{ Kedai Kopi Inspirasi } & \multirow[b]{2}{*}{$\begin{array}{l}\text { Nilai } \\
\text { Sig.* }\end{array}$} \\
\hline & & $\begin{array}{c}\text { Frekuensi } \\
\text { (Orang) }\end{array}$ & $\begin{array}{c}\text { Persentase } \\
(\%)\end{array}$ & $\begin{array}{c}\text { Frekuensi } \\
\text { (Orang) }\end{array}$ & $\begin{array}{c}\text { Persentase } \\
(\%)\end{array}$ & \\
\hline 1 & Bersih & 20 & 74 & 8 & 18 & \multirow{5}{*}{0,000} \\
\hline 2 & $\begin{array}{l}\text { Kurang } \\
\text { bersih }\end{array}$ & 7 & 26 & 33 & 73 & \\
\hline 3 & Tidak bersih & - & - & 4 & 9 & \\
\hline & Total & 27 & 100 & 45 & 100 & \\
\hline \multicolumn{3}{|c|}{ Peringkat rata-rata* } & 49.69 & \multicolumn{2}{|c|}{28.59} & \\
\hline
\end{tabular}

Ket: *Berdasarkan hasil Mann-Whitney U Test

Jika dibandingkan antara Jigana Coffee Shop dan Kedai Kopi Inspirasi, persentase responden yang berpendapat bahwa kebersihan dan kerapihan kedai kopi masih kurang bersih lebih banyak di Kedai Kopi Inspirasi. Hal ini karena masih terdapat empat responden yang memilih pilihan tidak bersih. Alasan dari sebagian responden yang merasa bahwa Kedai Kopi Inspirasi ini masih tidak bersih yaitu karena kedai kopi ini bertemakan wood and vintage sehingga cenderung menimbulkan kesan yang kotor. Selain itu, terdapat banyak puntung rokok yang bertebaran, sampah daun kering yang jatuh, toilet yang kurang bersih dan meja yang basah sehingga harus lebih diperhatikan kembali oleh Kedai Kopi Inspirasi, khususnya pada saat musim hujan. Harapan dari sebagian konsumen terhadap kebersihan dan kerapihan Kedai Kopi Inspirasi ini yaitu agar pihak kedai dapat meningkatkan standar kebersihan kedai agar konsumen yang datang merasa nyaman berada di Kedai Kopi Inspirasi.

\section{6) Suasana Kedai}

Selanjutnya, variabel yang diteliti adalah suasana tempat. Suasana kafe adalah kombinasi antara karakteristik fisik toko seperti tata letak, warna, arsitektur, pencahayaan, temperature, musik, aroma yang secara menyeluruh dapat menciptakan citra yang baik dibenak konsumen itu sendiri (Utami, 2010). Suasana tempat ini merupakan salah satu faktor penting yang perlu diperhatikan karena semakin komunikatif suasana exterior kafe dan semakin nyaman interior kafe makan akan membuat konsumen betah berlama-lama di dalam kunjungan. Hasil analisis perbandingan respons konsumen mengenai suasana di Jigana Coffee Shop dan Kedai Kopi Inspirasi tersaji pada Tabel 6.

Hasil Mann-Whitney $U$ Test pada Tabel 6 menunjukkan bahwa tidak terdapat perbedaan yang signifikan (nilai sig. $=0,170>$ taraf nyata $5 \%$ ) dalam hal suasana kedai antara Jigana Coffee Shop dan Kedai Kopi 
Inspirasi. Hal ini mengindikasikan bahwa konsumen menilai bahwa suasana kedai yang ditawarkan Jigana Coffee Shop dan Kedai Kopi Inspirasi adalah sama.

Tabel 6

Hasil Analisis Perbandingan Respons Konsumen Mengenai Suasana Jigana Coffee Shop dan Kedai Kopi Inspirasi

\begin{tabular}{|c|c|c|c|c|c|c|}
\hline \multirow[b]{2}{*}{ No. } & \multirow{2}{*}{$\begin{array}{c}\text { Respons } \\
\text { Suasana } \\
\text { Kedai }\end{array}$} & \multicolumn{2}{|c|}{ Jigana Coffee Shop } & \multicolumn{2}{|c|}{ Kedai Kopi Inspirasi } & \multirow{2}{*}{$\begin{array}{l}\text { Nilai } \\
\text { Sig.* }\end{array}$} \\
\hline & & $\begin{array}{l}\text { Frekuensi } \\
\text { (Orang) }\end{array}$ & $\begin{array}{c}\text { Persentase } \\
(\%)\end{array}$ & $\begin{array}{l}\text { Frekuensi } \\
\text { (Orang) }\end{array}$ & $\begin{array}{c}\text { Persentase } \\
(\%)\end{array}$ & \\
\hline 1 & $\begin{array}{l}\text { Sangat } \\
\text { menarik }\end{array}$ & 9 & 33 & 24 & 53 & \multirow{5}{*}{0,170} \\
\hline 2 & $\begin{array}{l}\text { Kurang } \\
\text { menarik }\end{array}$ & 18 & 67 & 19 & 42 & \\
\hline 3 & $\begin{array}{l}\text { Tidak } \\
\text { menarik }\end{array}$ & - & - & 2 & 5 & \\
\hline & Total & 27 & 100 & 45 & 100 & \\
\hline \multicolumn{3}{|c|}{ Peringkat rata-rata* } & 2.67 & \multicolumn{2}{|c|}{38.80} & \\
\hline
\end{tabular}

Ket: *Berdasarkan hasil Mann-Whitney U Test

Mayoritas responden Jigana Coffee Shop berpendapat bahwa suasana tempat yang disediakan kedai kopi tersebut kurang menarik. Pilihan tersebut mendapatkan persentase terbesar, yaitu 67 persen. Hal ini disebabkan oleh beberapa alasan, diantaranya yaitu suasana yang masih didalam kios sehingga masih terkesan kaku serta desain interior yang masih belum dapat menghidupkan suasana.

Berbeda dengan Kedai Kopi Inspirasi yang mayoritas respondennya berpendapat bahwa suasana tempat yang disediakan sudah sangat menarik. Hal tersebut karena konsep nature bernuansa negeri forest dengan didukung oleh furniture kayu jati ini sangat menarik dan menjadikan Kedai Kopi Inspirasi ini memiliki ciri khas dan keunikan tersendiri. Selain itu juga dengan konsep seperti itu, kedai kopi ini terlihat asri sehingga membuat konsumen merasa nyaman dengan suasana tempat yang ditawarkan oleh kedai kopi ini.

Selain itu, nilai peringkat rata-rata suasana di Kedai Kopi Inspirasi memang lebih besar dari pada kedai Jigana Coffee Shop (Tabel 6), namun demikian secara keseluruhan berdasarkan hasil uji statistic harus disimpulkan bahwa tidak ada perbedaan yang signifikan antar keduanya.

\section{7) Kestrategisan Lokasi Kedai}

Buchari Alma (2003) dalam Hayat (2012) mengemukakan bahwa lokasi merupakan tempat perusahaan beroperasi serta melakukan kegiatan untuk menghasilkan suatu produk maupun jasa yang mementingkan segi ekonominya. Penempatan lokasi bisnis merupakan unsur penentu kepuasan konsumen. Lokasi penjualan yang strategis akan memberikan efisiensi serta kemudahan bagi konsumen untuk melakukan proses pembelian (Tjiptono, 2004; dalam Wirawan dkk., 2019). Hasil analisis perbandingan respons konsumen mengenai kestrategisan lokasi Jigana Coffee Shop dan Kedai Kopi Inspirasi tersaji pada Tabel 7.

Hasil Mann-Whitney $U$ Test pada Tabel 7 menunjukkan bahwa terdapat perbedaan yang signifikan (nilai sig. $=0,000<$ taraf nyata $5 \%$ ) dalam hal kestartegisan lokasi kedai antara Jigana Coffee Shop dan
Kedai Kopi Inspirasi. Dengan nilai peringkat rata-rata kebersihan dan kerapihan kedai Jigana Coffee Shop yang lebih besar dari pada Kedai Kopi Inspirasi mengindikasikan bahwa konsumen menilai bahwa Jigana Coffee Shop lebih strategis dari pada Kedai Kopi Inspirasi.

Tabel 7

Hasil Analisis Perbandingan Respons Konsumen Mengenai Kestrategisan Lokasi Jigana Coffee Shop dan Kedai Kopi Inspirasi

\begin{tabular}{|c|c|c|c|c|c|c|}
\hline \multirow[b]{2}{*}{ No. } & \multirow{2}{*}{$\begin{array}{c}\text { Respons } \\
\text { Kestrategisan } \\
\text { Lokasi }\end{array}$} & \multicolumn{2}{|c|}{ Jigana Coffee Shop } & \multicolumn{2}{|c|}{ Kedai Kopi Inspirasi } & \multirow{2}{*}{$\begin{array}{l}\text { Nilai } \\
\text { Sig.* }\end{array}$} \\
\hline & & $\begin{array}{c}\text { Frekuensi } \\
\text { (Orang) }\end{array}$ & $\begin{array}{c}\text { Persentase } \\
(\%)\end{array}$ & $\begin{array}{c}\text { Frekuensi } \\
\text { (Orang) }\end{array}$ & $\begin{array}{c}\text { Persentase } \\
(\%)\end{array}$ & \\
\hline 1 & Strategis & 14 & 52 & 6 & 14 & \multirow{5}{*}{0,000} \\
\hline 2 & $\begin{array}{l}\text { Kurang } \\
\text { strategis }\end{array}$ & 13 & 48 & 24 & 54 & \\
\hline 3 & Tidak strategis & - & - & 15 & 33 & \\
\hline & Total & 27 & 100 & 45 & 100 & \\
\hline Per & ingkat rata-rata* & \multicolumn{2}{|c|}{48.78} & \multicolumn{2}{|c|}{29.13} & \\
\hline
\end{tabular}

Ket: *Berdasarkan hasil Mann-Whitney U Test

Berdasarkan Tabel 7, dapat diketahui bahwa mayoritas responden Jigana Coffee Shop berpendapat bahwa lokasi usaha kedai kopi ini sudah strategis. Hal ini dikarenakan lokasi kedai kopi ini berada di pinggir Jalan Raya Alternatif Cibinong-Bogor-Depok, dan dekat dengan pemukiman ramai sehingga mempermudah konsumen untuk dapat menemukan lokasi Jigana Coffee Shop. Berbeda halnya dengan Kedai Kopi Inspirasi yang mayoritas respondennya berpendapat bahwa lokasi dari kedai kopi ini masih kurang strategis karena letaknya berada di dalam gang, bukan di jalan raya utama.

Hal ini sesuai dengan uraian peneliti di awal bahwa Jigana Coffee Shop lokasinya strategis namun jumlah pengunjungnya sedikit dan mengalami tren penurunan penjualan, sedangkan Kedai Kopi Inspirasi yang lokasinya kurang begitu strategis namun lebih ramai pengunjung dan penjualannya cenderung meningkat.

\section{Kesimpulan}

Hasil penelitian menunjukkan bahwa dilihat dari struktur organisasi, suasana bekerja dan job description dari kedua kedai kopi ini cenderung sama. Hanya saja pemilik Kedai Kopi Inspirasi mempunyai visi dan misi selain mengenalkan dan meningkatkan konsumsi kopi masyarakat juga membuka lapangan kerja bagi orang yang putus sekolah disekitar lokasi usaha agar bisa tetap berpenghasilan dan dapat belajar lebih dalam mengenai kopi.

Hasil uji Mann-Whitney $U$ menunjukkan, dari 7 atribut preferensi konsumen yang diuji, Jigana Coffee Shop mendapatkan penilaian yang lebih baik dari konsumen ketimbang Kedai Kopi Inspirasi pada atribut kualitas produk, kualitas pelayanan, kebersihan dan kerapihan kedai, dan kestrategisan lokasi. Sedangkan untuk atribut harga, fasilitas dan suasana kedai tidak ada perbedaan yang nyata antara Jigana Coffee Shop dan Kedai Kopi Inspirasi.

Hasil tersebut mengidikasikan bahwa Jigana Coffee Shop memang mempunyai keunggulan dalam hal kualitas produk, kualitas pelayanan, kebersihan dan kerapihan 
kedai, dan kestrategisan lokasi dibandingkan Kedai Kopi Inspirasi. Namun Kedai Kopi Inspirasi ternyata tidak kalah dari Jigana Coffee Shop dalam hal keterjangkauan harga, kelengkapan fasilitas dan suasana kedai. Sehingga banyaknya pengunjung dan meningkatnya penjualan di Kedai Kopi Inspirasi tidak terlepas dari ketiga faktor tersebut.

\section{Daftar Pustaka}

Ajijah, N. (2019). Analisis Curahan Waktu Kerja Rumah Tangga Petani Pada Usahatani Kopi Arabika Di Kabupaten Aceh Tengah Dan Bener Meriah. ETD Unsyiah

Amir, N. H., Rasmikayati, E., \& Saefudin, B. R. (2017). Analisis usahatani kopi di kelompok tani hutan giri senang Desa Giri Mekar Kabupaten Bandung. Jurnal ilmiah mahasiswa agroinfo galuh, 3(3), 472-479.

Amridha, Y., Heryanto, M. A., Saefudin, B. R., \& Awaliyah, F. (2020). The Analysis of The Employee's Job Satisfaction and Performance In Private Agricultural Company. Mahatani: Jurnal Agribisnis (Agribusiness and Agricultural Economics Journal), 2(2).

Anisailah, R. (2017). Analisis Kualitas Produk dan Kualitas Pelayanan Barista di Krema Koffie Pekanbaru. 4(1), 1-16.

Asioli, D., N, T., Øvrum, A., \& Almli, V. L. (2016). Comparison of Rating-Based and Choice-Based Conjoint Analysis Models. A Case Study Based On Preferences for Iced Coffee In Norway. Food Quality and Preference, 48, 174-184. https://doi.org/10.1016/j.foodqual.2015.09.007.

Donaldson, T., \& Walsh, J. P. (2015). Toward a Theory of Business. Research in Organizational Behavior, 35, 181-207.

Faradisa, I., Budi, L., \& Minarsih, M. M. (2016). Analisis Pengaruh Variasi Produk, Fasilitas, dan Kualitas Pelayanan Terhadap Minat Beli Ulang Konsumen Pada Indonesian Coffee Shop Semarang (Icos Cafe). Manajemen, 2(2).

Febrianti, T., Tsani, A., \& Milla, A. N. (2019). Analisis Preferensi Konsumen Terhadap Sayuran Hidroponik Di Kota Sukabumi. Ilmiah Pertanian, 7(1), 1-8.

Gerry, Y., Mongan, P., Rumagit, G. A. J., Kumaat, R. M., Sosial, J., Pertanian, E., Sam, U. (2019). Tingkat Kepuasan Konsumen Di Rumah Kopi K8 Di Kota Manado. Agrirud, 1(2).

Hayat, A. W. M. (2012). Pengaruh Lokasi dan Citra Merek Terhadap Keputusan Pembelian Konsumen Pada Distro Ouval Research di Buah Batu Bandung. Jurnal UNIKOM, 1 - 16.

ICO. (2018). Monthly coffee market report.

Kara A, Kaynak E. 1997. Marketing Strategies For Fast Food Restaurants: A Customer View. British Food Journal.

Kotler, Philip. Gary Armstrong. 2012. Prinsip - Prinsip Pemasaran. Jakarta: Erlangga.

Kotler, Philip. Gary Armstrong. 2003. Dasar-Dasar Pemasaran. 9th ed. PT Indeks Kelompok Gramedia, Jakarta.

Kotler, Philip. \& Gary Armstrong. (2014). Principle of Marketing, 15th edition. New Jersey: Pearson Prentice Hall.

Latifa, N. H., \& Rochdiani, D. (2019). Kajian Strategi Pemasaran Usaha Kedai Kopi Kadaka Cafetaria di Kota Bandung. Agribisnis Dan Social Ekonomi Pertanian, 4(1).

Loo, E. J. Van, Caputo, V., Jr, R. M. N., Seo, H.-S., Zhang, B., \& Verbeke, Wi. (2015). Sustainability Labels On Coffee: Consumer Preferences, Willingness-To-Pay and Visual Attention to Attributes. Ecological Economics, 118, 215-225. https://doi.org/10.1016/j.ecolecon.2015.07.011

Lovelock, Christopher H. dan Wright, Lauren K.. 2002. Principles of Service Marketing and Management. Prentice Hall Inc., Upper Saddle River, New Jersey.

Mawson E, Fearne A. 1996. Purchasing Strategies and Decision-Making Processes In The Food Service Industry: A Case Study Of UK Restaurant Chains. Supply Chain Management International Journal 1.

Mullins, Orville, Larreche dan Boyd. (2005). Marketing Management: A Strategic Decision Making Approach, $6^{\text {th }}$ edition. Penerbit McgrawHill. New York City.

Psychogios, A., \& Garev, S. (2012). Understanding Complexity Leadership Behavior in Smes: Lessons From a Turbulent Business Environment, Emergence: Complexity \& Organization, 14, 1-22.
Rasmikayati, E., Pardian, P., Hapsari, H., Ikhsan, R. M., \& Saefudin, B. R. (2017). Kajian Sikap dan Perilaku Konsumen dalam Pembelian Kopi serta Pendapatnya Terhadap Varian Produk dan Potensi Kedainya. Mimbar Agribisnis: Jurnal Pemikiran Masyarakat Ilmiah Berwawasan Agribisnis, 3(2), 117-133.

Rasmikayati, E., Saefudin, B. R., Karyani, T., Kusno, K., \& Rizkiansyah, R. (2020). Analisis Faktor dan Tingkat Kepuasan Ditinjau dari Kualitas Produk dan Pelayanan pada Konsumen Sayuran Organik Di Lotte Mart Kota Bandung. Mimbar Agribisnis: Jurnal Pemikiran Masyarakat Ilmiah Berwawasan Agribisnis, 6(1), 351-364.

Rochaeni, S. (2013). Analisis Persepsi, Kesadaran, dan Preferensi Konsumen Terhadap Buah Lokal. Agribisnis, 7(1), 91-104.

Satit, Huam Hon Tat, Amran Rasli, Thoo Ai Chin, Inda Sukati. 2012. The Relationship Between Marketing Mix and Customer Decision Making Over Travel Agents: An Empirical Study. International Journal of Academic Research in Business and Social Sciences.

Sugiyono. 2018. Metode Penelitian Kuantitatif. Bandung: Alfabeta.

Tjiptono, Fandy. (2004). Strategi Pemasaran, Edisi 2. Yogyakarta: Penerbit.

Utami, C. (2010). Manajemen Ritel. Jakarta: Selemba Empat.

Wirawan, A. A., Sjahruddin, H., \& Razak, N. (2019). Pengaruh Kualitas Produk dan Lokasi Terhadap Loyalitas Pelanggan Melalui Kepuasan Pelanggan Sebagai Variabel Intervening Pada Lamuna Coffee di Kabupaten Bone. Organisasi Dan Manajemen, 1(1).

Yuriansyah, A. L. (2013). Persepsi Tentang Kualitas Pelayanan, Nilai Produk Dan Fasilitas Terhadap Kepuasan Pelanggan. Management Analysis Journal, 2(1). 